MEDDELANDEN FRÅN

SVENSKA HANDELSHÖGSKOLAN

SWEDISH SCHOOL OF ECONOMICS

AND BUSINESS ADMINISTRATION

WORKING PAPERS

478

Anders Ekholm \& Daniel Pasternack

OVERCONFIDENCE AND INVESTOR SIZE

NOVEMBER 2002 
Overconfidence and Investor Size

Key words: Investor size, Behavior, Overconfidence

JEL Classification: G10, G12, G14

(C) Swedish School of Economics and Business Administration, Anders Ekholm \& Daniel Pasternack

Anders Ekholm \& Daniel Pasternack

Department of Finance and Statistics

Swedish School of Economics and Business Administration

P.O.Box 479

00101 Helsinki, Finland

Distributor:

Library

Swedish School of Economics and Business Administration

P.O.Box 479

00101 Helsinki

Finland

Phone: +358-9-431 33 376, +358-9-431 33265

Fax: $\quad+358-9-43133425$

E-mail:publ@shh.fi

http://www.shh.fi/services/biblio/papers/index.htm

SHS intressebyrå IB (Oy Casa Security Ab), Helsingfors 2002

ISBN 951-555-755-0

ISSN 0357-4598 


\title{
Overconfidence and investor size
}

\author{
Anders Ekholm and Daniel Pasternack
}

\begin{abstract}
Recent research documents that institutional or large investors act as antagonists to other investors by showing opposite behavior following disclosure of new information. Using an extremely comprehensive official transactions data set from Finland, we set out to explore the interrelation between investor size and behavior. More specifically, we test whether investor size is positively (negatively) correlated with investor reaction following positive (negative) news. We document robust evidence of that investor size affects investor behavior under new information, as larger investors on average react more positively (negatively) to good (bad) news than smaller investors. In the light of this study it seems increasingly feasible that several recent findings of heterogeneous investor behavior are functions of differences in overconfidence.
\end{abstract}

JEL classification: G10; G12; G14

Keywords: investor size; behavior; overconfidence

* Corresponding author. Swedish School of Economics and Business Administration, P.O. Box 479, 00101 Helsinki, Finland; tel. +358-9-431 33 308; fax.+358-9-431 33 393; e-mail anders.ekholm@shh.fi

We are indebted to Juha-Pekka Kallunki, Eva Liljeblom, Joshua Livnat and Anders Löflund for comments and suggestions. We further gratefully acknowledge financial support received for the project from the Finnish Academy of Sciences, the Säästöpankkien Tutkimussäätiö and the Yrjö Jahnsson foundation. 


\section{Introduction}

Recent research by Lee (1992), Grinblatt and Keloharju (2000), Ekholm (2001) and Cohen et al. (2001) documents that large investors act as antagonists to other investors by showing opposite behavior following the disclosure of new information. The underlying dynamics of this systematic behavior however remain largely unexplored. Further, it seems increasingly feasible that investment decisions may be affected by psychological biases, such as overconfidence ${ }^{1}$. Ekholm(2001) suggests that differences in behavior when new information is disclosed are driven by differences in overconfidence, and that investor size is a good measure of overconfidence. The contribution of this study is to thoroughly explore the interrelation between investor overconfidence, size and behavior.

We document robust evidence of that investor size describes investor behavior under new information, as larger investors systematically react more positively (negatively) to good (bad) news than smaller investors. We feel confident that our findings are not an artifact of comparing extremely large investors with extremely small investors, as the behavior is found to be a fairly linear function of investor size. Our results lend firm support to that investor size is a good proxy for investor overconfidence, and that differences in overconfidence result in the observed behavior.

The study is organized as follows. Section 2 presents the hypotheses and discusses the implemented methodology. Section 3 describes the data. Results are displayed and analyzed in Section 4. Finally, section 5 summarizes the paper.

\section{Hypotheses and methodology}

In this section we first discuss how differences in overconfidence for different groups of investors will systematically affect trading between these groups. Further, we present the methodology employed in this paper.

\footnotetext{
1 See De Long et al. (1990, 1991), Kyle and Wang (1997), Benos (1998), Daniel et al. (1998), Odean (1998), Hong and Stein (1999), Gervais and Odean (2001), and Wang (2001) for theoretical models of overconfident investors in financial markets. Empirical evidence of investor overconfidence is presented by for instance Barber and Odean (2000, 2001), Locke and Mann (2001), and Tyynelä and Perttunen (2002).
} 


\subsection{Hypotheses}

As discussed by Odean (1998), overconfidence has been documented for individuals in numerous professions, e.g. nurses, engineers, attorneys and market professionals. Moreover, Barber and Odean (2000, 2001), Locke and Mann (2001) and Tyynelä and Perttunen (2002) document empirical evidence of some investors being overconfident, and Kyle and Wang (1997), Benos (1998) and Wang (2001) theoretically propose that overconfident investors can survive in a stock market.

Ekholm (2001) finds evidence indicating that investor size can be used as a proxy for the level of overconfidence. Further, Gervais and Odean (2001) theoretically show that the level of overconfidence decreases as an investor becomes more experienced, and Locke and Mann (2001) find empirical support for this. In the Gervais and Odean (2001) framework investors gain experience by participating in the stock market, and thus experience depends both on the amount of time spent in the stock market and the intensity of participation. We argue that investor size is a good proxy for investor experience, hence implying a negative relation between size and overconfidence. Our argument builds on that larger investment portfolios tend to on average be managed by investors who are more experienced than smaller investors. This is true, since the wealth of individual investors tends to increase with time, and experience. Furthermore, the wealthiest individuals and institutional investors ${ }^{2}$ consult investment professionals, who by default have above-average experience due to their extensive participation in the stock market. As overconfidence decreases with experience, it will thus also decrease with investor size.

Ekholm(2001) models the trading behavior of groups exhibiting different levels of overconfidence when new information arrives to the marketplace. We use the framework of Ekholm (2001), presented next, in order to understand how trading behavior under new information varies for groups showing different levels of overconfidence.

Let us assume that the stock market is populated by two types of investors, $\mathrm{S}$ and $\mathrm{U}$, of which

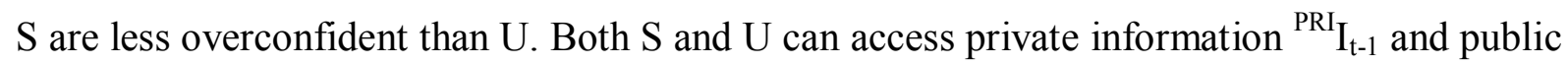
information ${ }^{\text {PUB }} \mathrm{I}_{\mathrm{t}-1}$ at time $\mathrm{t}-1$. The value they view as correct for a company is determined as

\footnotetext{
${ }^{2}$ E.g. mutual funds, which also manage small investors' pooled assets.
} 
a function, ${ }^{\mathrm{S}} \mathrm{f}(\bullet)$ for investors of type $\mathrm{S}$ and ${ }^{\mathrm{U}} \mathrm{f}(\bullet)$ for investors of type $\mathrm{U}$, of both types of information.

$$
\begin{aligned}
& { }^{\mathrm{S}} \mathrm{V}_{\mathrm{t}-1}={ }^{\mathrm{S}} \mathrm{f}\left({ }^{\mathrm{PRI}} \mathrm{I}_{\mathrm{t}-1},{ }^{\mathrm{PUB}} \mathrm{I}_{\mathrm{t}-1}\right) \\
& { }^{\mathrm{U}} \mathrm{V}_{\mathrm{t}-1}={ }^{\mathrm{U}} \mathrm{f}\left({ }^{\mathrm{PRI}} \mathrm{I}_{\mathrm{t}-1},{ }^{\mathrm{PUB}} \mathrm{I}_{\mathrm{t}-1}\right)
\end{aligned}
$$

In equilibrium, the value perceived as correct by the two types of investors of a company at time $\mathrm{t}-1$, when no new information is available on the market, equals the market value.

$$
{ }^{\mathrm{S}} \mathrm{V}_{\mathrm{t}-1}={ }^{\mathrm{U}} \mathrm{V}_{\mathrm{t}-1}=\mathrm{V}_{\mathrm{t}-1}
$$

At time $t$ new public information ${ }^{\mathrm{PUB}} \mathrm{I}_{\mathrm{t}}$ arrives to the market, which would to the fully rational investor indicate a shift ${ }^{\mathrm{PUB}} \Delta \mathrm{V}_{\mathrm{t}}$ in the value of the company. However, since the two types of investors $\mathrm{S}$ and $\mathrm{U}$ are overconfident, they will give the new public information less weight than the fully rational investor. The perceived new value is thus

$$
\begin{array}{lll}
{ }^{\mathrm{S}} \mathrm{V}_{\mathrm{t}}=\mathrm{V}_{\mathrm{t}-1}+{ }^{\mathrm{S}} \mathrm{W} *{ }^{\mathrm{PUB}} \Delta \mathrm{V}_{\mathrm{t}} & \text { where } & 0<{ }_{\mathrm{W}}<1 \\
{ }^{\mathrm{U}_{\mathrm{t}}}=\mathrm{V}_{\mathrm{t}-1}+{ }^{\mathrm{U}} \mathrm{W} *{ }^{\mathrm{PUB}} \Delta \mathrm{V}_{\mathrm{t}} & \text { where } & 0<{ }_{\mathrm{W}}<1
\end{array}
$$

Since investors of type $S$ are less overconfident than investors of type $U$, investors of type $S$ give more weight to new public information than investors of type $U$, thus ${ }{ }_{w}>{ }^{U}$. We now get

$$
\begin{array}{lll}
{ }^{\mathrm{S}} \mathrm{V}_{\mathrm{t}}>{ }^{\mathrm{U}} \mathrm{V}_{\mathrm{t}} & \text { if } & { }^{\mathrm{PUB}} \Delta \mathrm{V}>0 \\
{ }^{\mathrm{S}} \mathrm{V}_{\mathrm{t}}<{ }^{\mathrm{U}} \mathrm{V}_{\mathrm{t}} & \text { if } & { }^{\mathrm{PUB}} \Delta \mathrm{V}<0 \\
{ }^{\mathrm{S}} \mathrm{V}_{\mathrm{t}}={ }^{\mathrm{U}} \mathrm{V}_{\mathrm{t}} & \text { if } & { }^{\mathrm{PUB}} \Delta \mathrm{V}=0
\end{array}
$$

Hence, when public information that is interpreted as positive (negative) by the fully rational investor arrives to the market, the value perceived as correct by the less overconfident investors $\mathrm{S}$ will be higher (lower) than the value perceived as correct by the more overconfident investors $U$. If the new public information is interpreted as neutral by the fully rational investor, all investor types will agree on the value of the company. It is important to note that the conclusions also hold when investors of type $\mathrm{S}$ are fully rational investors $\left({ }^{\mathrm{S}} \mathrm{W}=\right.$ 1). The implications for transaction behavior under new information are apparent: when the 
market receives positive (negative) public information regarding a company, less overconfident investors will buy (sell) company stock from (to) the more overconfident investors, until a new valuation equilibrium is reached.

As a direct consequence of that investor size proxies investor overconfidence and of the framework presented above, we arrive at the following two hypotheses:

H1: On the arrival of news that is interpreted as positive by the market, larger investors on average react more positively than do smaller investors.

H2: On the arrival of news that is interpreted as negative by the market, larger investors on average react more negatively than do smaller investors.

It is apparent that the above-presented hypotheses require investor-specific transaction records in order to be testable. The methodology utilized for testing the two hypotheses is described next.

\subsection{Methodology}

The investigation of our hypotheses requires us to 1) identify positive and negative news events, 2) measure investors' reactions to these events and 3) measure investor size.

\subsubsection{Identifying news}

We identify positive and negative news by first calculating the cumulative abnormal return (CAR) for all periods subsequent ${ }^{3}$ to firm specific announcement dates and then extracting the most extreme news events with respect to the CARs ${ }^{4}$. This methodology enables us to identify news events that have had a "true" impact on the firm value, or in other words contain substantial information regarding the firms. By selecting extreme events we decrease the risk of spurious results due to events that lack information substantially changing the prospects of the firm.

\footnotetext{
${ }^{3}$ The cumulative abnormal returns are calculated for 7 calendar days (day 0 to day +6 ). The length of the event window is set to a full calendar week, as one-week abnormal returns are less exposed to model misspecification and market noise.

${ }^{4}$ The extreme news identified by extracting the by CARs measured $2.5 \%$ most positive and $2.5 \%$ most negative events.
} 
Abnormal returns used to create CARs are calculated by subtracting expected returns for each stock and day from the corresponding realized returns. Expected returns are calculated according to the market model methodology ${ }^{5}$. For each stock and each day, daily returns for the preceding 365 calendar days ${ }^{6}$ are first OLS regressed against corresponding return data for the HEX Portfolio Index ${ }^{7}$. The expected returns are then calculated for each stock and each day by implementing the market model estimates and actual returns for the HEX Portfolio Index.

\subsubsection{Measuring reaction}

Investors' reactions to the disclosure of new firm-specific information is gauged by first identifying all investors who have traded in the firm's stock S during the calendar week after the disclosure ${ }^{8}$, including the day of disclosure, from the Finnish Central Securities Depository central register. The net holdings before $\left({ }^{\mathrm{I},} \mathrm{S}_{\mathrm{NH}}\right)$ and after $\left({ }^{\mathrm{I}, \mathrm{S}} \mathrm{NH}_{\mathrm{t}+6}\right)$ the event are then calculated for each investor separately by aggregating the initial balance and all transactions up to and including date $t-1$ and $t+6$. An investor reaction proxy ${ }^{I, S} R_{t, t+6}$ is calculated for investor I, stock $\mathrm{S}$ and disclosure date $\mathrm{t}$ according to the following:

$$
\begin{array}{lll}
{ }^{\mathrm{I}, \mathrm{S}} \mathrm{R}_{\mathrm{t}, \mathrm{t}+6}=\left({ }^{\mathrm{I}, \mathrm{S}} \mathrm{NH}_{\mathrm{t}+6}{ }^{\mathrm{I}, \mathrm{S}} \mathrm{NH}_{\mathrm{t}-1}\right) /{ }^{\mathrm{I}, \mathrm{S}} \mathrm{NH}_{\mathrm{t}+6} & \text { if } & { }^{\mathrm{I}, \mathrm{S}} \mathrm{NH}_{\mathrm{t}+6}-{ }^{\mathrm{I}, \mathrm{S}} \mathrm{NH}_{\mathrm{t}-1}>0 \\
{ }^{\mathrm{I}, \mathrm{S}} \mathrm{R}_{\mathrm{t}, \mathrm{t}+6}=\left({ }^{\mathrm{I}, \mathrm{S}} \mathrm{NH}_{\mathrm{t}+6}{ }^{\mathrm{I}, \mathrm{S}} \mathrm{NH}_{\mathrm{t}-1}\right) /{ }^{\mathrm{I}, \mathrm{S}} \mathrm{NH}_{\mathrm{t}-1} & \text { if } & { }^{\mathrm{I}, \mathrm{S}} \mathrm{NH}_{\mathrm{t}+6}-{ }^{\mathrm{I}, \mathrm{S}} \mathrm{NH}_{\mathrm{t}-1}<0 \\
{ }^{\mathrm{I}, \mathrm{S}} \mathrm{R}_{\mathrm{t}, \mathrm{t}+6}=0 & \text { if } & { }^{\mathrm{I}, \mathrm{S}} \mathrm{NH}_{\mathrm{t}+6}{ }^{\mathrm{I}}{ }^{\mathrm{I}, \mathrm{S}} \mathrm{NH}_{\mathrm{t}-1}=0
\end{array}
$$

where ${ }^{I, S} R_{t, t+6}$ is the reaction proxy for investor I and stock $S$ for the time period $t$ to $t+6$, , ${ }^{\mathrm{S}} \mathrm{NH}_{\mathrm{t}+6}$ is the net holding in stock $\mathrm{S}$ for investor I at time $\mathrm{t}+6$, and ${ }^{\mathrm{I}, \mathrm{S}} \mathrm{NH}_{\mathrm{t}-1}$ is the net holding in stock $\mathrm{S}$ for investor I at time $\mathrm{t}-1$

\footnotetext{
${ }^{5}$ See Campbell et al. (1997), pages 149-180.

${ }^{6}$ A minimum of $365 * 5 / 7 * 90 \%=234$ daily return observations is required to form a valid market model for each stock and event. Valid return data is hence required for $90 \%$ of the weekdays.

${ }^{7}$ The HEX Portfolio Index is a value weighted index where all firms listed on the main list of the Helsinki Stock Exchange (HEX) are represented. However, the weight of any individual firm is limited to 10\% thus eliminating the dominance of a few big firms listed on the HEX (especially Nokia).

${ }^{8}$ Investor reactions are monitored for one calendar week after the disclosure of information in order to guarantee that the information is available to all investors.
} 
The above defined measure ${ }^{\mathrm{I}, \mathrm{S}} \mathrm{R}_{\mathrm{t}, \mathrm{t}+6}$ hence expresses the following. If investor I has increased his/her net holding in stock $\mathrm{S}$ during the time period $\mathrm{t}$ to $\mathrm{t}+6$, the measure expresses the fraction of the final position at time $\mathrm{t}+6$ that has been acquired during the event window. On the other hand, if investor I has decreased his/her net holding in stock S during the time period $t$ to $t+6$, the measure expresses the fraction of the initial position at time $t-1$ that has been sold out during the event window. Finally, if investor I has traded in stock $\mathrm{S}$ during the time period $\mathrm{t}$ to $\mathrm{t}+6$, but not changed his/her net holding, the measure takes the value 0 . Clearly, the above defined investor reaction proxy will be a continuous function taking values $[-1,1]$. Further, the investor reaction proxy is symmetric, which is important in order to not introduce a bias in the variable.

An obvious alternative when measuring investor reaction is to calculate the simple change in $\mathrm{I}$, ${ }^{\mathrm{S}} \mathrm{NH}$ during the time period $\mathrm{t}$ to $\mathrm{t}+6$. The above defined approach is however preferred for one fundamental and two econometric reasons. First, we believe that the investor reaction proxy defined in equations (9), (10) and (11) better expresses how investors themselves perceive their actions 9 . Second, if we employ the simple changes methodology an econometric problem occurs when the initial position ${ }^{\mathrm{I},}{ }^{\mathrm{S}} \mathrm{NH}_{\mathrm{t}-1}$ equals zero (division by zero). Third, the simple changes methodology by default induces a bias in ${ }^{\mathrm{I}, \mathrm{S}} \mathrm{R}_{\mathrm{t}, \mathrm{t}+6}$ since the distribution is asymmetric, taking values $\left[-1, \infty\left[\right.\right.$ when ${ }^{\mathrm{I},} \mathrm{NH}_{\mathrm{t}-1} \neq 0$.

Another alternative when measuring investor reaction is to employ a discrete framework, by for instance assigning the reaction proxy variable the value 0 for decreases in holdings and 1 for increases in holdings. However, by moving into a discrete framework we lose the magnitude of the reaction, as only the direction of the investor reactions remains. In summary, the in equations (9), (10) and (11) proposed and in this study employed way of measuring investor reaction enables us to measure both the direction and the magnitude of the investor reactions, however avoiding the pitfalls of the simple changes methodology.

\footnotetext{
${ }^{9}$ This argument is primarily derived from the situation where we have small denominators. For instance, if an investor owns 100 shares and then acquires 1000 more, the percentage change would be $1100 / 100-1=$ $1000 \%$. The corresponding measure according to equation (1) would on the other hand take the value (1100-100) $/ 1100=91 \%$, which seems somewhat more intuitive.
} 


\subsubsection{Measuring investor size}

We create an investor size variable by dividing the observations for each firm separately into 10 equally large groups according to the net holding in number of shares at date t-1 and assigning the values 1 (smallest $10^{\text {th }}$ of initial holding) to 10 (largest 10th). The investor size identification is done for each firm separately in order to avoid having any investor group excessively dominated by transactions in a few firms. Investor size is hence defined as a relative measure among investors that trade in the same stock. Further, we exclude observations where the initial number of shares equals zero, due to short sale constraints.

\section{The data}

The total data set used in the study consists of 1) the Finnish Central Securities Depository central register data set and 2) firm-specific news announcements.

\subsection{The Finnish Central Securities Depository Central Register data set}

The employed transaction data set is, to the best of our knowledge, one of the most comprehensive and complete transaction data sets that have been employed in this field of research up to this date. The Finnish Central Securities Depository central register contains virtually all transactions for the stocks of listed Finnish companies during the time period December 281994 to May 302000 with daily accuracy. The data set covers approximately $97 \%$ of the total market capitalization of the Helsinki Stock Exchange as of the beginning of the sample period, as reported by Grinblatt and Keloharju (2000), and further expands to cover all traded companies from the middle of the investigated period onwards. The Finnish Central Securities Depository central register is the official register of ownership, controlled by the Finnish Financial Supervision Authority, and can hence be viewed as extremely reliable and accurate. Altogether the data set consists of 25,400,767 observations for a total of 1,050,412 different investors, complete with transaction information (notification date, price, volume etc.) and investor characteristics information (investor type, birth year, postal code, sex etc.). A settlement lag of three trading days is conventional on the Helsinki Stock Exchange and the date stamps in the data set include this lag, which is adjusted for in the empirical analysis presented below. Due to this three-day settlement lag, the transactions in the database are stamped between January 21995 and June 2 2000, and the initial balance as of December 271994 is stamped as January 11995. 
Investors are categorized into six major groups according to their legal status. These six groups are further divided into several subgroups according to more specific characteristics. All Finnish individuals and institutions are required to register their holdings in their own name, but foreigners can choose to act in the name of a nominee. The holdings of foreigners that choose to act in a nominee name are pooled together into larger pools with the holdings of the nominee. However, the data set contains information that can be utilized to discriminate between transactions executed by foreigners and by the nominee itself. The task of disintegrating the foreigners acting in nominee names further into different subtypes, such as individuals and institutions, is however made impossible by nominee registration. Further, the register does not separate indirect shareholdings through financial institutions, such as mutual funds. Indirect holdings are registered in the names of the financial institutions, and are thus treated as property of the financial institutions in this study. This is well in line with the purpose of this study, as financial institutions by Finnish law must exercise full control over the investment policy of their indirect holdings.

\subsection{Firm-specific news announcements}

We identify positive and negative news by first retrieving ${ }^{10}$ the announcement dates for all firm specific news disclosures during the time period 1.5.1996-30.4.2001 for the 15 by EUR volume most traded ${ }^{11}$ stocks on the Helsinki Stock Exchange. Altogether this procedure results in 2430 unique news items, when we delete multiple news items for the same day and firm and exclude events for which we could not calculate CARs. As all firms listed on the HEX are compelled to submit their news items through the HEX, the gathered news items represent a rather complete coverage of firm specific news. When we extract the extreme $5 \%$ of the total news items, the final event sample contains 61 positive and 61 negative news items.

\footnotetext{
${ }^{10}$ All price and volume data is retrieved from the Datastream information service.

${ }^{11}$ In order to avoid the pitfalls of infrequent trading, the 15 most traded stocks are identified on an annual basis by computing the daily EUR turnover and aggregating these turnovers up to yearly values. This procedure identifies altogether 28 stocks that belong to the 15 most traded stocks for some of the investigated years. We feel confident that limiting our study to the 15 most traded stocks on the HEX does not damage generalization of our results, as globally significant stock markets as a rule offer even higher liquidity than the liquidity for these 15 stocks.
} 


\subsection{Summary statistics}

The total data set containing all investors' reactions to the 122 news disclosures, consists of 45,858 observations. Descriptive statistics presented in Table 1 reveals that transactions executed by households constitute the largest single group with 22,559 observations for positive news events ( $83.3 \%$ of total) and 15,218 observations for negative (81.1\% of total). Companies and Financial institutions constitute the second and third largest group of observations, respectively.

\section{Table 1 - Investor reactions following positive and negative news for the main FCSD investor categories}

Table 1 displays the number of investor reaction observations for the investigated disclosures of significant firmspecific news for Finnish firms. The sample is divided into reactions to positive and negative news and further into the six major investor categories defined by the Finnish Central Securities Depository central register. Altogether 61 positive and 61 negative news events were investigated during the time period of 1.5.199630.4.2001.

\section{Positive news}

\begin{tabular}{lrr}
\multicolumn{1}{c}{ Group } & N & \% of total \\
\hline Companies & 2717 & $10.0 \%$ \\
Financial institutions & 1137 & $4.2 \%$ \\
General government & 242 & $0.9 \%$ \\
Nonprofit organizations & 248 & $0.9 \%$ \\
Households & 22559 & $83.3 \%$ \\
Countries and International Organizations & 182 & $0.7 \%$ \\
& & \\
All positive & 27085 & $100.0 \%$
\end{tabular}

\section{Negative news}

\begin{tabular}{lrr}
\multicolumn{1}{c}{ Group } & $\mathrm{N}$ & $\%$ of total \\
\hline Companies & 1765 & $9.4 \%$ \\
Financial institutions & 1100 & $5.9 \%$ \\
General government & 318 & $1.7 \%$ \\
Nonprofit organizations & 252 & $1.3 \%$ \\
Households & 15218 & $81.1 \%$ \\
Countries and International Organizations & 120 & $0.6 \%$ \\
& & \\
All negative & 18773 & $100.0 \%$ \\
& & \\
\hline
\end{tabular}

The one-week cumulative abnormal returns following the disclosure of firm-specific news, displayed in Table 2, reveal that the CARs on average are equal to zero and thus do not show signs of any systematic bias due estimation problems. The average CARs for the negative and positive events clearly deviate from zero as expected. Further, we find that the average CARs 
for the negative and positive events are of same magnitude in absolute terms, indicating fairly symmetric extreme tails in the news distribution.

\section{Table 2 - Distribution of cumulative abnormal returns}

Table 2 displays one-week ( $\mathrm{t}=0$ to $\mathrm{t}=6$ ) abnormal returns for periods subsequent to firm specific news disclosures for the 15 most traded shares on the Helsinki Stock Exchange during the time period 1.5.1996-30.4.2001. The 15 most traded shares are evaluated on an annual basis by the daily EUR volume, resulting in altogether 28 stocks belonging to this group during the overall time period. Abnormal returns are calculated using 365 calendar day market models. The positive (negative) event groups include the events with the $2.5 \%$ most positive (negative) CARs.

\begin{tabular}{lrrrrr}
\hline \multicolumn{1}{c}{ Event type } & $\mathrm{N}$ & \multicolumn{1}{c}{ Mean } & \multicolumn{1}{c}{ SEM } & \multicolumn{1}{c}{ t-value } & \multicolumn{1}{c}{ p-value } \\
\hline Positive $(2.5 \%)$ & 61 & $22.8 \%$ & $1.0 \%$ & 21.98 & 0.00 \\
Negative $(2.5 \%)$ & 61 & $-23.6 \%$ & $1.4 \%$ & -16.89 & 0.00 \\
All & 2430 & $0.0 \%$ & $0.2 \%$ & -0.15 & 0.88 \\
& & & & & \\
\hline
\end{tabular}

\section{Results}

The average reaction to positive news for different investor size groups is displayed in Table 3. The fact that all size groups on average significantly decrease their holdings is explained by that all investors, regardless of absolute size, receive equal weights when the averages are calculated for the reaction variables. Hence, for the market to clear, this finding implies that the largest investors on the market on average increase their holdings when positive information is disclosed. Our findings lend support to our first hypothesis, predicting that larger investors will interpret positive information more favorably than do smaller investors, as larger investors on average react more positively to positive information than do smaller investors ${ }^{12}$.

Furthermore, the framework presented above also predicts that the magnitude of the disagreement between more and less overconfident investors will depend on the magnitude of the news. This prediction is supported by the extremely significant differences ${ }^{13}$ in the average

\footnotetext{
${ }^{12}$ The correlation coefficient between the number of the investor size group (1-10) and the average reaction to positive news for the group is 0.50 .

${ }^{13}$ For instance, the average reaction of Group 10 is significantly larger than that of Group 9, yielding a t-value of 12.0 .
} 
reactions of the different size groups, as we here investigate the $2.5 \%$ most positive news events.

\section{Table 3 - Investor reactions following positive news for different investor size groups}

Table 3 displays average investor reactions to the disclosure of positive firm specific news. Positive events are defined as the $2.5 \%$ events with the most positive CARs. One-week CARs are calculated for periods subsequent to firm specific news disclosures for the 15 most traded shares on the Helsinki Stock Exchange during the time period 1.5.1996-30.4.2001. Investor reaction is measured as the number of stocks bought (sold) during the week consecutive to the event divided by the total terminal (initial) number of stocks held. The investor reaction proxy hence expresses how a certain investor changes his/her holding in a certain company during the week after the disclosure of the news. Investor size groups are created by dividing the observations into 10 equally large groups according to the net holding in number of shares at date $\mathrm{t}-1$ for each firm separately. The investor size identification is done for each firm separately in order to avoid having any investor group excessively dominated by transactions in few firms. Investor size is hence defined as a relative measure among investors that trade in the same stock.

\begin{tabular}{lrrrrr}
\hline \multicolumn{1}{c}{ Group } & N & Average & SEM & t-value & p-value \\
\hline Group 1 - Smallest 10th of initial holding & 2723 & $-37.3 \%$ & $1.4 \%$ & -25.73 & 0.00 \\
Group 2 & 2708 & $-52.4 \%$ & $1.3 \%$ & -40.73 & 0.00 \\
Group 3 & 2707 & $-54.4 \%$ & $1.2 \%$ & -45.37 & 0.00 \\
Group 4 & 2709 & $-55.3 \%$ & $1.2 \%$ & -47.85 & 0.00 \\
Group 5 & 2701 & $-55.6 \%$ & $1.1 \%$ & -51.76 & 0.00 \\
Group 6 & 2714 & $-51.1 \%$ & $1.1 \%$ & -48.24 & 0.00 \\
Group 7 & 2710 & $-48.9 \%$ & $1.0 \%$ & -47.79 & 0.00 \\
Group 8 & 2706 & $-44.3 \%$ & $1.0 \%$ & -44.63 & 0.00 \\
Group 9 & 2709 & $-40.4 \%$ & $1.0 \%$ & -41.29 & 0.00 \\
Group 10 - Largest 10th of initial holding & 2698 & $-24.7 \%$ & $0.9 \%$ & -28.40 & 0.00 \\
\hline
\end{tabular}

The average reaction to negative news for different investor size groups, displayed in Table 4, reveal that larger investors on average react more negatively to negative news than do smaller investors ${ }^{14}$. This trend in the average reactions for the different size group hence confirms our second hypothesis, which predicts that larger investors react more negatively to negative news than do smaller investors.

\footnotetext{
${ }^{14}$ The correlation coefficient between the number of the investor size group (1-10) and the average reaction to negative news for the group takes the very convincing value of -0.96 .
} 
Table 4 - Investor reactions following negative news for different investor size groups

Table 4 displays average investor reactions to the disclosure of negative firm specific news. Negative events are defined as the $2.5 \%$ events with the most negative CARs. One-week CARs are calculated for periods subsequent to firm specific news disclosures for the 15 most traded shares on the Helsinki Stock Exchange during the time period 1.5.1996-30.4.2001. Investor reaction is measured as the number of stocks bought (sold) during the week consecutive to the event divided by the total terminal (initial) number of stocks held. The investor reaction proxy hence expresses how a certain investor changes his/her holding in a certain company during the week after the disclosure of the news. Investor size groups are created by dividing the observations into 10 equally large groups according to the net holding in number of shares at date $\mathrm{t}-1$ for each firm separately. The investor size identification is done for each firm separately in order to avoid having any investor group excessively dominated by transactions in few firms. Investor size is hence defined as a relative measure among investors that trade in the same stock.

\begin{tabular}{lrrrrr}
\hline \multicolumn{1}{c}{ Group } & N & Average & SEM & t-value & p-value \\
\hline Group 1 - Smallest 10th of initial holding & 1888 & $11.8 \%$ & $1.7 \%$ & 7.15 & 0.00 \\
Group 2 & 1877 & $2.5 \%$ & $1.6 \%$ & 1.55 & 0.12 \\
Group 3 & 1878 & $3.2 \%$ & $1.5 \%$ & 2.10 & 0.04 \\
Group 4 & 1877 & $1.0 \%$ & $1.4 \%$ & 0.68 & 0.50 \\
Group 5 & 1874 & $-0.8 \%$ & $1.4 \%$ & -0.54 & 0.59 \\
Group 6 & 1879 & $-5.3 \%$ & $1.4 \%$ & -3.75 & 0.00 \\
Group 7 & 1879 & $-8.4 \%$ & $1.3 \%$ & -6.23 & 0.00 \\
Group 8 & 1876 & $-9.6 \%$ & $1.3 \%$ & -7.26 & 0.00 \\
Group 9 & 1879 & $-9.9 \%$ & $1.2 \%$ & -8.49 & 0.00 \\
Group 10 - Largest 10th of initial holding & 1866 & $-10.4 \%$ & $1.0 \%$ & -10.55 & 0.00 \\
\hline
\end{tabular}

Figure 1 displays the average reactions to both positive and negative news for the different size groups. The positive correlation between average reaction and investor size under positive news is apparent, as is the negative correlation under negative news. At this point, facing these staggering strong results, we feel that it is important to remind ourselves of that if all investors interpret and react to information equally, there is absolutely no reason to expect an average reaction different from zero for any group of investors. 


\section{Figure 1 - Average reactions of different investor size groups to positive and negative news}

Figure 1 displays the average investor reactions to the disclosure of positive and negative firm specific news. Events are defined as the $2.5 \%$ events with the most positive (negative) CARs. One-week CARs are calculated for periods subsequent to firm specific news disclosures for the 15 most traded shares on the Helsinki Stock Exchange during the time period 1.5.1996-30.4.2001. Investor reaction is measured as the number of stocks bought (sold) during the week consecutive to the event divided by the total terminal (initial) number of stocks held. The investor reaction proxy hence expresses how a certain investor changes his/her holding in a certain company during the week after the disclosure of the news. Investor size groups are created by dividing the observations into 10 equally large groups according to the net holding in number of shares at date t-1 for each firm separately. The investor size identification is done for each firm separately in order to avoid having any investor group excessively dominated by transactions in few firms. Investor size is hence defined as a relative measure among investors that trade in the same stock.

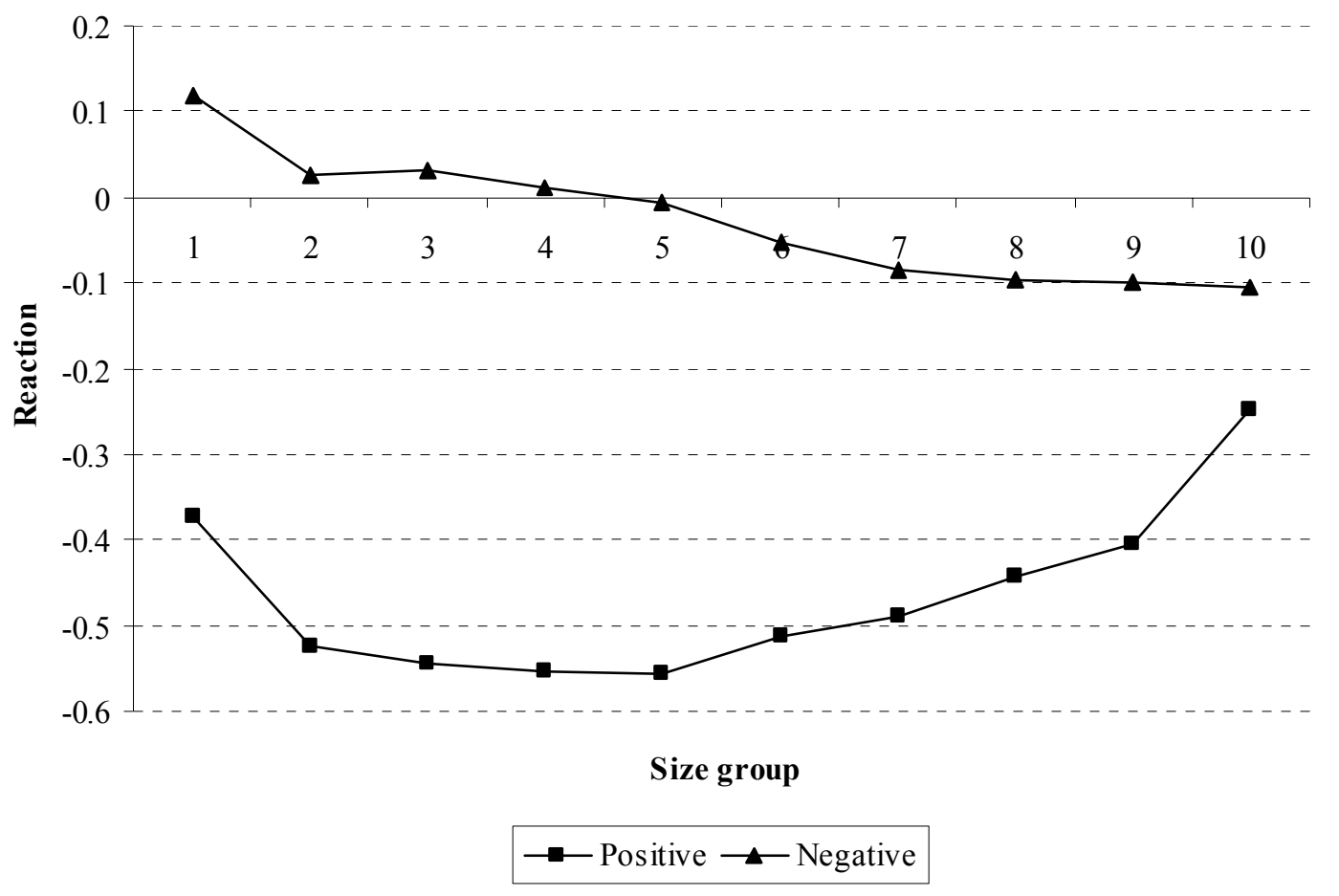

We further regress the reaction for each investor on the investor-size variable in order to verify the results presented above. The regression results presented in Table 5 confirm that investor size is positively (negatively) related to investor reaction to positive (negative) news. Interestingly enough, we find that the estimated coefficients for the investor size variable furthermore are rather equal in magnitude ( 0.016 for positive news and -0.023 for negative news). 


\section{Table 5 - OLS regression results for positive and negative news}

Table 5 displays the OLS regression estimates for negative and positive news events. An investor reaction proxy, which expresses how a certain investor changes his/her holding in a certain company during the week after the disclosure of positive or negative news, is OLS regressed against the investor size group number (1-10). Investor reaction is measured as the number of stocks bought (sold) during the week consecutive to the event divided by the total terminal (initial) number of stocks held. Investor size groups are created by dividing the observations into 10 equally large groups according to the net holding in number of shares at date $\mathrm{t}-1$ for each firm separately. The investor size identification is done for each firm separately in order to avoid having any investor group excessively dominated by transactions in few firms. Investor size is hence defined as a relative measure among investors that trade in the same stock.

\begin{tabular}{lrrrlrrr}
\hline \multicolumn{3}{c}{ Positive news } & & & \multicolumn{3}{c}{ Negative news } \\
& \multicolumn{2}{c}{} & & & & & \\
& Estimate & $\mathrm{t}$-value & $\mathrm{p}$-value & & Estimate & t-value & $\mathrm{p}$-value \\
\hline Intercept & -0.555 & -71.78 & 0.0000 & Intercept & 0.102 & 10.70 & 0.0000 \\
Size $(1-10)$ & 0.016 & 13.16 & 0.0000 & Size $(1-10)$ & -0.023 & -15.12 & 0.0000 \\
& & & & & & & \\
$\mathrm{~N}$ & 27085 & & & $\mathrm{~N}$ & 18773 & & \\
$\mathrm{R}^{\wedge} 2$ & $0.6 \%$ & & & $\mathrm{R}^{\wedge} 2$ & $1.2 \%$ & & \\
& & & & & & & \\
\hline
\end{tabular}

Our findings gain support from Lee (1992), as he documents a positive correlation between large buy (sell) orders and positive (negative) earnings news. Further, the Bartov et al. (2000) find that firms that to a higher degree are owned by institutional investors display smaller post earnings-announcement abnormal returns. They argue that institutional investors are more sophisticated and thus incorporate the new information more promptly than other investors. In the light of our study it seems feasible that the results presented by Bartov et al. (2000) could be driven by differences in overconfidence. Our findings also confirm the findings of Ekholm (2001), as he finds that large investors react more positively (negatively) following positive (negative) earnings surprises than do small investors. In addition, Cohen et al. (2001) also document that large investors increase (decrease) their holdings in a stock in response to positive (negative) cash flow news. Again, it seems feasible that these results are driven by differences in investor overconfidence.

\subsection{Robustness tests}

The impressive size and span of the data set employed in this study certainly reduces the risk of spurious results due to a biased sample. However, we perform a set of robustness tests in order to further ensure the validity of the central findings in this study. 
We split the data for both negative and positive news events into two equally large subsamples according to date of disclosure. We then redo the regressions presented in Table 5 for the four sub samples. We find that the parameter estimates for the models estimated on the sub-samples are essentially equal ${ }^{15}$ to the parameter estimates estimated for the full samples (Table 5). We hence feel confident that it is highly unlikely that the results in this study are due to random properties of the investigated data sample.

\subsection{Alternative explanations}

The evidence presented above shows that investor reaction to news is conditional on investor size. Furthermore, the evidence lends strong support to that differences in overconfidence is the source of the heterogeneous behavior. However, in the following we consider some alternative explanations for the observed empirical findings.

\subsubsection{Portfolio rebalancing}

Especially larger investors frequently employ investment strategies where the weight of any stock in the portfolio is limited ${ }^{16}$. Thus, for these investors, large price increases for some specific stock occasionally induces selling activity in order to decrease the weight of that stock. This scenario hence implies that large investors on average should be keener towards selling after large positive price increases than small investors ${ }^{17}$. We conclude that this phenomenon does not seem to explain our findings, as we find that large investors are keener towards increasing (decreasing) their holdings following extremely positive (negative) news, than their smaller counterparts.

\subsubsection{Lagging order book}

Arguably there could exist differences between different investors regarding the availability of information. For instance, if smaller investors on average receive information later than larger investors, larger investors could utilize smaller investors' orders in the order book in

\footnotetext{
${ }^{15}$ For instance, all significant parameter estimates in the full sample are of the same sign in the corresponding sub-samples. The specific results for the robustness tests are available on request.

${ }^{16}$ For instance, mutual funds registered in Finland can by law not have more than $10 \%$ of the total assets invested in a single stock.

${ }^{17}$ It is important to note that index-based investment strategies do naturally not imply any excess trading activity after large price increases or decreases, as the weights of the stocks in the portfolio automatically will adjust with the weights of the index.
} 
order to achieve favorable prices. Thus, larger investors would buy (sell) all lagging sell (buy) orders in the order book following positive (negative) news. However, as the investor reactions are monitored for a full calendar week and the average depth of the order book is only a fraction of the daily traded volume, we are convinced that this is not the explanation for our empirical findings.

\subsubsection{Liquidity constraints}

Even though we have investigated the 15 most traded stocks it is reasonable to assume that large investors to some degree suffer from liquidity constraints. In practice liquidity constraints imply that larger investors cannot sell or buy as aggressively as they would wish to. Hence this should lead to large investors' reacting more moderately than smaller investors. In terms of our reaction measure, this implies an in absolute terms lesser average reaction for larger investors than for smaller investors. Our findings however show that following negative news, the absolute value of the average reaction for the largest investors (size group 10) is larger than the corresponding values for investor size groups 2 to 9 . Hence, our findings cannot be explained by liquidity constraints.

\subsubsection{Initial holding}

As mentioned above we exclude investors with zero initial holding in the stock due to short sale constraints. However, investors with initial holdings less than a stock exchange round lot will in some cases face sale constraints. This will result in an upward bias for the reaction variable for the smallest investor group. We observe indications of this problem in our results, as the average reaction for size group 1 is significantly larger than that of group 2, for both negative and positive news. However, the problem is limited to the smallest size group and will neither alter the results for the other size groups nor our conclusions.

\subsection{Economic implications}

In order to examine economic consequences of the behavior of the different size groups we calculate cumulative abnormal returns (CAR) for each investor separately ${ }^{18}$. The CARs are

\footnotetext{
${ }^{18}$ All CARs are calculated using 365 calendar day market models where a minimum of $365 * 5 / 7 * 90 \%=234$ daily return observations are required to form a valid market model for each stock and event.
} 
cumulated from $\mathrm{t}=3$ onwards $(\mathrm{t}=0 \text { being the event day })^{19}$. A specific investor's CAR is calculated by assigning the stock's CAR (CAR multiplied by -1) if the investor increases (decreases) his/her holding. Figure 2 displays the average CARs for the investor size groups for different time periods following positive news. The results do not indicate systematic differences in cumulative abnormal returns between the different size groups, suggesting that the difference in investor reactions on average result in equal returns for different size groups following positive news.

${ }^{19}$ The data set created in this study does not reveal the exact dates when trades occurred. However, we feel that the assumption that at least half of the trades that are executed during the calendar week after the disclosure of new information occur during the first three days $(t=0$ to $t=2)$, is very reasonable. 


\section{Figure 2 - Cumulate abnormal returns following positive news for different size groups}

Figure 2 displays the average cumulative abnormal returns (CAR) for the 10 different size groups of investors after the disclosure of positive firm specific news. CARs are cumulated from $t=3$ onwards, hence assuming that at least half of the trades during the week ( $\mathrm{t}=0$ to $\mathrm{t}=6$ ) after news disclosures occur during the first three days $(t=0$ to $t=2)$. An investor's CAR is calculated by assigning the stock's CAR (CAR multiplied by -1 ) if the investor increases (decreases) his/her holding. All CARs are calculated using 365 calendar day market models where a minimum of $365 * 5 / 7 * 90 \%=234$ daily return observations are required to form a valid market model for each stock and event. Positive news events are defined as the $2.5 \%$ events with the most positive $t=0$ to $t=6$ CARs. CARs are calculated for periods subsequent to firm specific news disclosures for the 15 most traded shares on the Helsinki Stock Exchange during the time period 1.5.1996-30.4.2001. Investor size groups are created by dividing the observations into 10 equally large groups according to the net holding in number of shares at date t-1 for each firm separately. The investor size identification is done for each firm separately in order to avoid having any investor group excessively dominated by transactions in few firms. Investor size is hence defined as a relative measure among investors that trade in the same stock.

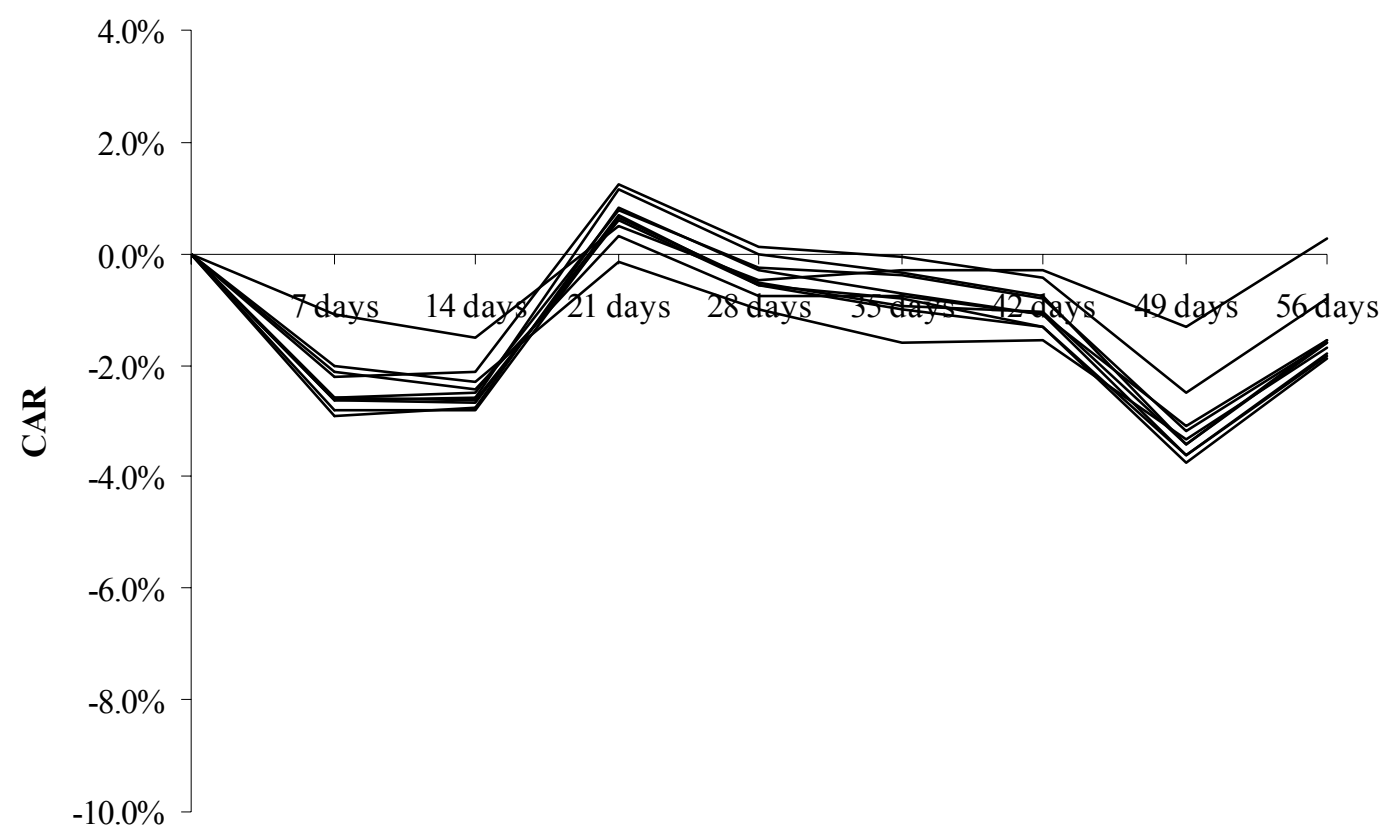

Days after event day +2 
The average CARs for the investor size groups for different periods following negative news are displayed in Figure 3. Interestingly enough, the results suggest persistent differences in the subsequent average cumulative abnormal returns for the different size groups following negative news. For instance, the 56-day average CAR for size group 10 is significantly positive (with a t-value of 2.53), while the corresponding CAR for size group 1 is significantly negative (with a t-value of -15.84). Furthermore, the differences between the groups are extremely persistent; the inferences do not change for different time periods. Indeed, the drift in the average CARs for the different size groups appears to be as large for the second half of the time period as for the first half. 


\section{Figure 3 - Cumulate abnormal returns following negative news for different size groups}

Figure 3 displays the average cumulative abnormal returns (CAR) for the 10 different size groups of investors after the disclosure of negative firm specific news. CARs are cumulated from $\mathrm{t}=3$ onwards, hence assuming that at least half of the trades during the week ( $\mathrm{t}=0$ to $\mathrm{t}=6$ ) after news disclosures occur during the first three days $(t=0$ to $t=2)$. An investor's CAR is calculated by assigning the stock's CAR (CAR multiplied by -1 ) if the investor increases (decreases) his/her holding. All CARs are calculated using 365 calendar day market models where a minimum of $365 * 5 / 7 * 90 \%=234$ daily return observations are required to form a valid market model for each stock and event. Negative news events are defined as the $2.5 \%$ events with the most negative $t=0$ to $t=6$ CARs. CARs are calculated for periods subsequent to firm specific news disclosures for the 15 most traded shares on the Helsinki Stock Exchange during the time period 1.5.1996-30.4.2001. Investor size groups are created by dividing the observations into 10 equally large groups according to the net holding in number of shares at date t-1 for each firm separately. The investor size identification is done for each firm separately in order to avoid having any investor group excessively dominated by transactions in few firms. Investor size is hence defined as a relative measure among investors that trade in the same stock.

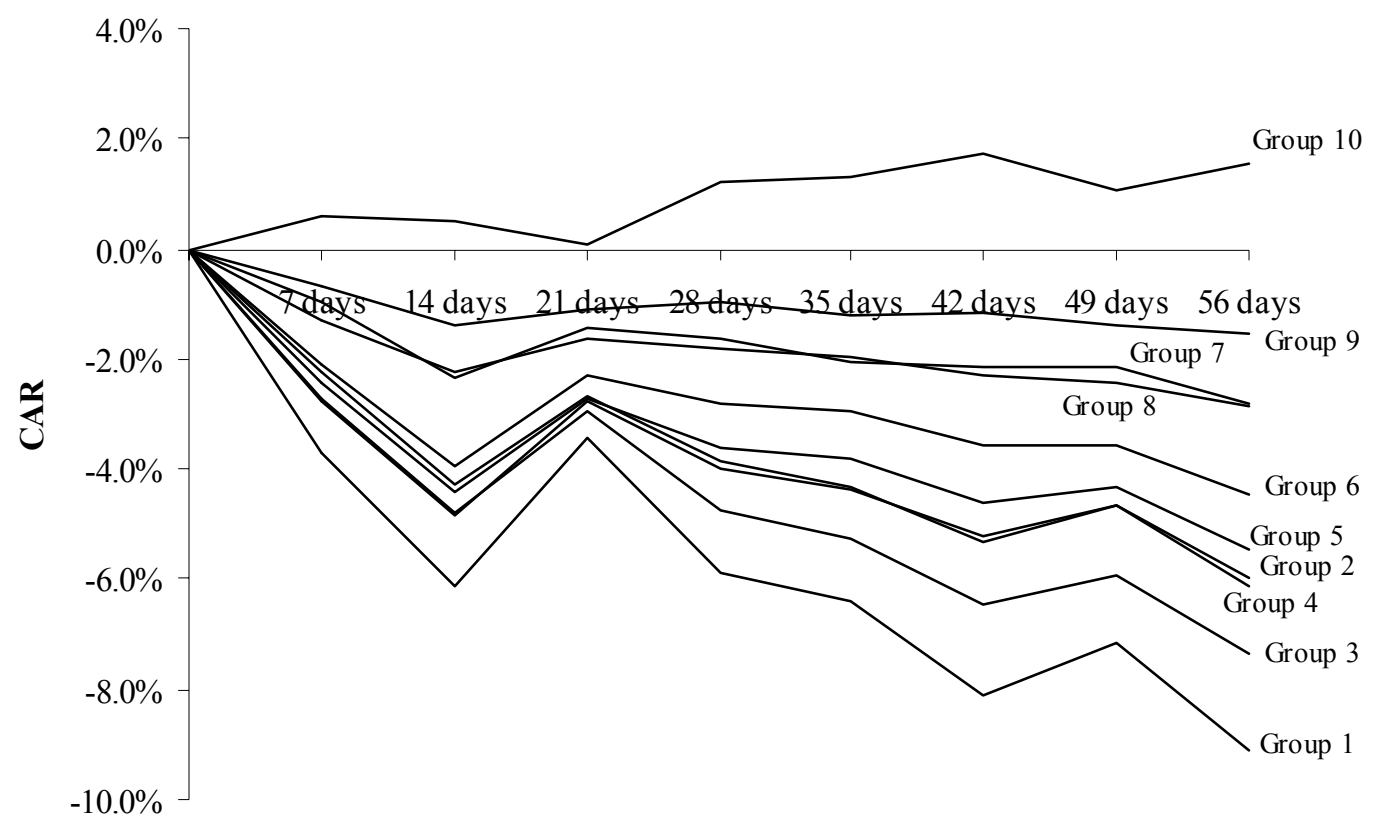

Days after event day +2 


\section{Summary}

A priori, it is hard to motivate any deviation from the assumption that investors on average behave homogenously. However, recent research documents that institutional or large investors act as antagonists to other investors by showing opposite behavior following disclosure of new information. Ekholm (2001) argues that this difference in behavior is driven by differences in overconfidence, and that investor size seems to be a good measure of overconfidence. The framework presented in Gervais and Odean (2001) further supports investor size being a good proxy for overconfidence, as larger investment portfolios tend to be managed by investors who are more experienced than smaller investors.

We set out to test a hypothesis that larger investors are less overconfident than smaller investors, and thus will react more positively (negatively) to positive (negative) news. We employ an extremely comprehensive official transactions data set from Finland, which allows us to monitor the actions of each investor following the disclosure of new information.

We document robust evidence of that investor size describes investor behavior under new information, as larger investors on average react more positively (negatively) to good (bad) news than do smaller investors. Our findings lend firm support to our hypothesis, which states that larger investors are less overconfident than smaller investors. We consider several alternative explanations, but are forced to reject all of them. Furthermore, we investigate the economic implications of the documented behavior, and find evidence of significant differences between the performances of the different investor size groups after disclosures of negative news. We find that the performance of smaller, or more overconfident, investors is in general hurt by their behavior following negative news.

In the light of these results, it seems increasingly feasible that several recent findings of heterogeneous investor behavior are functions of differences in overconfidence. 


\section{REFERENCES}

Barber, B. and T. Odean, 2000, Trading is hazardous to your wealth: The common stock investment performance of individual investors, Journal of Finance 55, 773-806.

Barber, B. and T. Odean, 2001, Boys will be boys: Gender, overconfidence, and common stock investment, Quarterly Journal of Economics, 261-292.

Bartov, E., S. Radhakrishnan and I. Krinsky, 2000, Investor sophistication and patterns in stock returns after earnings announcements, The Accounting Review 75, 43-63.

Benos, A., 1998, Aggressiveness and survival of overconfident traders, Journal of Financial Markets 1, 353-383.

Campbell J., A. Lo and A. MacKinlay, 1997, The Econometrics of Financial Markets, (Princeton University Press).

Cohen, R.B, P.A. Gompers and T. Vuolteenaho, 2001, Who underreacts to cash-flow news: Evidence from trading between individuals and institutions. Working paper, Harvard University.

Daniel, K., D. Hirshleifer and A. Subrahmanyam, 1998, Investor psychology and security market under- and overreactions, Journal of Finance 53, 1839-1885.

De Long, J, A. Shleifer, L. Summers and R. Waldmann, 1990, The survival of noise traders in financial markets, Journal of Business 64, 1-19.

De Long, J, A. Shleifer, L. Summers and R. Waldmann, 1991, Noise trader risk in financial markets, Journal of Political Economy 98, 703-738.

Ekholm, A., 2001, How do different types of investors react to new financial statement information? Working Paper 464, Swedish School of Economics and Business Administration.

Gervais, S. and T. Odean, 2001, Learning to be overconfident, The Review of Financial Studies 14, 1-27. 
Grinblatt, M. and M. Keloharju, 2000, The investment behavior and performance of various investor types: a study of Finland's unique data set, Journal of Financial Economics 55, 43-67.

Hong, H. and J.C. Stein, 1999, A unified theory of underreaction, momentum trading, and overreaction in asset markets, Journal of Finance 54, 2143-2184.

Kyle, A. and F. Wang, 1997, Speculation duopoly with agreement to disagree: Can overconfidence survive the market test? Journal of Finance 52, 2073-2090.

Lee, C.M.C., 1992, Earnings news and small traders, Journal of Accounting and Economics $15,265-302$.

Locke, P.R. and S.C. Mann, 2001, House Money and Overconfidence on the Trading Floor, Unpublished Working Paper, Texas Christian University.

Odean, T., 1998, Volume, volatility, price, and profit when all traders are above average, Journal of Finance 53, 1887-1934.

Tyynelä, M. and J. Perttunen, 2002, Trading behavior of Finnish households: Activity, performance and overconfidence, Unpublished Working Paper, University of Oulu.

Wang, F.A., 2001, Overconfidence, investor sentiment, and evolution, Journal of Financial Intermediation 10, 138-170. 